\title{
Effect of dietary supplementation of trace elements on the lipid peroxidation in broiler meat assessed after a refrigerated and frozen storage ${ }^{*}$
}

\author{
V. Petrovič ${ }^{1,4}$, S. Marcinčák ${ }^{2}$, P. Popelka², L. Nollet ${ }^{3}$ and G. Kováč ${ }^{1}$
}

\author{
University of Veterinary Medicine, \\ ${ }^{1}$ Clinic of Ruminants, \\ ${ }^{2}$ Department of Food Hygiene and Technology \\ 04181 Košice, Slovak Republic \\ ${ }^{3}$ Alltech Netherlands $B V$ \\ Gensesteenweg 190, 9800 Deinze, Belgium
}

(Received 31 October 2008; revised version 31 March 2009; accepted 24 June 2009)

\begin{abstract}
The aim of this study was to determine the effect of dietary supplementation of $\mathrm{Cu}, \mathrm{Zn}, \mathrm{Fe}, \mathrm{Mn}$ and Se on the lipid peroxidation in broiler meat assessed after the refrigerated and frozen storage. Broiler chicks Ross 308 were randomly divided at the day of hatching into 4 groups and fed for 42 days with the diets containing a different amount and form of $\mathrm{Cu}, \mathrm{Fe}, \mathrm{Zn}, \mathrm{Mn}$ and $\mathrm{Se}$. The diets for the $1^{\text {st }}$ and $2^{\text {nd }}$ group of birds were supplemented with the equivalent amounts of trace elements in an inorganic form (Cu sulphate, $5 \mathrm{mg} / \mathrm{kg}$; Fe sulphate, $\mathrm{Zn}$ oxide and $\mathrm{Mn}$ oxide, $50 \mathrm{mg} / \mathrm{kg}$ ), however sodium selenite or selenized yeast were given in a dose of Se $0.3 \mathrm{mg} / \mathrm{kg}$, respectively. The $3^{\text {rd }}$ and $4^{\text {th }}$ group received the same feed as chickens in the $1^{\text {st }}$ and $2^{\text {nd }}$ group but with the highly reduced amount of supplemented nutrients in the organic "proteinated" form (Bioplex Cu, $2.5 \mathrm{mg} / \mathrm{kg}$; Bioplex Fe, Bioplex $\mathrm{Zn}$ and Bioplex Mn, $10 \mathrm{mg} / \mathrm{kg}$ ), except of selenium which was given in a dose of Se $0.3 \mathrm{mg} / \mathrm{kg}$ as sodium selenite or selenized yeast, respectively. The diet supplemented with the trace elements in the proteinated forms that were restricted to $50 \%(\mathrm{Cu}), 20 \%(\mathrm{Fe}, \mathrm{Zn}$ and $\mathrm{Mn}$ ) and on its regular level (Se) had the same effect on the carcass weight, weight of breast and thigh parts and the concentration of trace minerals in a muscle (except of Se) as the feeding of diet with the recommended dose of inorganic nutrients. The selenized yeast was shown to be more effective in the formation of Se deposit in the muscle of broilers than sodium selenite. On the other hand, the feeding of diet supplemented only with inorganic forms of $\mathrm{Cu}, \mathrm{Fe}, \mathrm{Zn}, \mathrm{Mn}$ and $\mathrm{Se}$ influenced the quality of broiler meat assessed after the refrigerated and frozen storage. The peroxide value and malondialdehyde value increased significantly in breast and thigh muscle of chickens in this
\end{abstract}

\footnotetext{
* Supported by Grant Agency for Science, VEGA of Slovak Republic, Grant No. 1/3486/06 and by Science and Research Assistance Agency, Grant No. APVV-20-027-905

${ }^{4}$ Corresponding author: e-mail: vpetrovic@centrum.sk
} 
group, what could be possibly explained by the negative interactions between sodium selenite and transition metal ions when supplemented in the form of inorganic salts.

KEY WORDS: broiler chickens, meat, trace elements, lipid peroxidation, refrigerated, frozen storage

\section{INTRODUCTION}

The naturally favourable fatty acids profile in the chicken meat is a reason of increasing interest at the expense of the beef cuts (Carnevale de Almeida et al., 2006). Chicken meat contains a higher level of polyunsaturated fatty acids (Pípová et al., 1995), which have a beneficial effect on the human health. A big demerit of this meat is that during its storage a large degradation of lipid fractions is promoted, whose severity positively correlated with the concentration of polyunsaturated fatty acids (Cortinas et al., 2005). The processes causing the oxidative degradation of lipids are called lipid peroxidation (LPO) and are initiated by free radicals.

The free radicals are involved in the uncontrolled chain reaction that primarily affect the phospholipids. The cell membrane phospholipids are particularly susceptible to the oxidative damage. During the lipoperoxidative process, the peroxyl radicals are generated and prolong the subsequent chain reaction leading to lipohydroperoxides and lipid radicals, which form new radicals and make from these reactions a vicious circle. The lipohydroperoxides are easily decomposed to aldehydes, ketones, alcohols and lactones, which could significantly affect the organoleptic characteristics of poultry meat after their accumulation (Higgins et al., 1999), being potentially toxic for humans. Lipohydroperoxides, peroxyl radicals and hydroperoxides generated within the initiation and propagation of LPO can induce a further damage of proteins and DNA (Tirosh and Reznick, 2000). Therefore, the determination of malondialdehyde and other secondary products of LPO is routinely used for the assessment of meat deterioration.

It is widely established that a deficient as well as excessive intake of trace elements could cause an oxidative stress (e.g., lipid peroxidation) in poultry (Surai, 2002), but the negative consequences of LPO can be overcome by the adequate supplementation of antioxidants into the diet. $\mathrm{Cu}, \mathrm{Zn}, \mathrm{Fe}, \mathrm{Mn}$ and $\mathrm{Se}$ are considered as antioxidant nutrients, $\mathrm{Fe}$ as a part of catalase, $\mathrm{Cu}, \mathrm{Zn}$ and $\mathrm{Mn}$ as a part of superoxide dismutase and Se as a part of glutathione peroxidase and all have an interdependent role in the antioxidant protection of organism by the termination of LPO reactions. On the contrary, the same elements as the trasitional metal ions have the ability to generate highly reactive hydroxyl radical through their interaction with reactive oxygen species (Aruoma et al., 1991).

The aim of this study was to determine the effect of dietary supplementation of $\mathrm{Cu}, \mathrm{Zn}, \mathrm{Fe}, \mathrm{Mn}$ and $\mathrm{Se}$ on the lipid peroxidation in broiler meat assessed after 24 
and $72 \mathrm{~h}$ of refrigerated as well 2 and 6 months of frozen storage, respectively.

\section{MATERIAL AND METHODS}

\section{Animals, diets and treatments}

Two hundred unsexed broilers Ross 308, were randomly divided at the day of hatching into 4 groups ( 50 per group) and were fed for 42 days with the diets containing a different amount and form of $\mathrm{Cu}, \mathrm{Fe}, \mathrm{Zn}, \mathrm{Mn}$ and Se. The diets were fed ad libitum during a whole experimental period for the healthy development of broiler chickens with free access to water. The broiler feed "Starter" was fed for the $1^{\text {st }}$ to $21^{\text {st }}$ day, the broiler feed "Grower" for the $21^{\text {st }}$ to $35^{\text {th }}$ day and the broiler feed "Finisher" for the $35^{\text {th }}$ to $42^{\text {nd }}$ day, respectively. The diets and Bioplex $\mathrm{Cu}$, Bioplex $\mathrm{Fe}$, Bioplex Zn, Bioplex Mn and Sel-Plex were prepared and purchased from Alltech Inc. (Belgium). All premixes were fortified with phytase and xylanase, and a coccidiostatic preparation was complemented into the diets for the $1^{\text {st }}$ to $35^{\text {th }}$ day of the broiler's life. The composition of diets fed to the broiler chickens during the entire experimental period is presented in Table 1.

Table 1. The composition of diets fed to the broiler chickens Ross 308 during the entire experimental period

\begin{tabular}{lccc}
\hline Component, g/kg of DM & Starter & Grover & Finisher \\
& $1-21$ day & $21-35$ day & $35-42$ day \\
\hline Wheat & 534.5 & 566.6 & 566.6 \\
Peas & 100 & 100 & 100 \\
Rapeseed meal (32\% CP) & 30 & 25 & 25 \\
Soyabean meal (46.5\% CP, $1.5 \%$ fat) & 250 & 220 & 220 \\
Palm oil & 25 & 35 & 35 \\
Soya oil & 25 & 25 & 25 \\
Premix ${ }^{1}$ & 5 & 5 & 5 \\
Limestone & 14.5 & 11.5 & 11.5 \\
Monocalcium phosphate & 8 & 3.5 & 3.5 \\
Natuphos 5000G (phytase) & 0.1 & 0.1 & 0.1 \\
NaCl & 2.2 & 2.2 & 2.2 \\
NaHCO & 2 & 2 & 2 \\
L-lysine & 1.5 & 1.5 & 1.5 \\
DL-methionine & 2 & 2 & 2 \\
L-threonine & 0.5 & 0.6 & 0.6 \\
\hline
\end{tabular}

$1 \mathrm{~kg}$ of basal diet contained, g: dry matter 879 , crude protein 201 , crude fat 73 , ash 45 , crude fibre 31, lysine 11.3, methionine 4.8, methionine+cystine 8.2, threonine 7.6, tryptophan 2.4, valine 9, arginine 12.9, histidine 5, Ca 6.8, P 4.5, Na 1.5, K 8.6, $\mathrm{Cl}^{-}$2, $\mathrm{Cu} 10$; mg: $\mathrm{Fe} \mathrm{150,} \mathrm{Zn} \mathrm{35,} \mathrm{Mn} \mathrm{15,} \mathrm{Se}$ 0.1 ; ME broiler $12.31 \mathrm{MJ} ;{ }^{1}$ premix supplied per $\mathrm{kg}$ of basal diet, IU: vit. A, 10000, vit. $\mathrm{D}_{3} 3000$, vit. E 20; mg: vit. K 3, thiamine 2, riboflavin 8, niacin 15 , cholinchlorid 50, pantothenic acid 50, pyridoxine 5 , folic acid 2 , biotin 0.2 , I 2 , Co $1 ; \mu \mathrm{g}$ : cyanocobalamin 30 
During the whole experiment, the broiler chickens in the $1^{\text {st }}$ and $2^{\text {nd }}$ group were fed with the diet supplemented with $\mathrm{Cu} 5 \mathrm{mg} / \mathrm{kg} \mathrm{DM}$ (Cu sulphate), Fe, $\mathrm{Zn}$ and $\mathrm{Mn}$ $50 \mathrm{mg} / \mathrm{kg} \mathrm{DM}$ (Fe sulphate, Zn oxide, Mn oxide), and Se $0.3 \mathrm{mg} / \mathrm{kg} \mathrm{DM}$ in a form of sodium selenite or selenized yeast, respectively. The $3^{\text {rd }}$ and $4^{\text {th }}$ group received the same feed supplemented with highly reduced dose of trace elements (except of $\mathrm{Se}$ ) in the proteinated forms: $\mathrm{Cu}, 2.5 \mathrm{mg} / \mathrm{kg} \mathrm{DM}$ (Bioplex $\mathrm{Cu}$ ), $\mathrm{Fe}, \mathrm{Zn}$ and $\mathrm{Mn}$, $10 \mathrm{mg} / \mathrm{kg}$ DM (Bioplex Fe, Bioplex Zn, Bioplex Mn) and Se, $0.3 \mathrm{mg} / \mathrm{kg}$ DM in the form of sodium selenite or selenized yeast (Sel-Plex), respectively.

At the $1^{\text {st }}$ day of life the broiler chicks were placed in one-level cages. The lighting regime was 23L:1D till the end of experiment. The initial room temperature $32^{\circ} \mathrm{C}$ was reduced every week by $3^{\circ} \mathrm{C}$ to a final temperature of $22-23^{\circ} \mathrm{C}$. From $2^{\text {nd }}$ to $5^{\text {th }}$ day of age, the birds received an antibiotic (Enroxyl 5\% premix, UNI Biotech) at the dose $0.5 \mathrm{ml}$ per litre and Newcastle disease vaccine (AVIPEST Lyof., Mevak a.s.) was applied on the $18^{\text {th }}$ day of life. Both preparations were given into the drinking water.

The protocol was approved by the Local Ethical and Scientific Authorities.

\section{Sample analysis}

On the $42^{\text {nd }}$ day of experiment, the broiler chickens were slaughtered by decapitation. Bleeding of chickens followed after the stunning in accordance with the rules established for the slaughtering of animals and it was performed by the responsible veterinary surgeon (Bugarský et al., 2003). For the detection of lipid peroxidation (LPO) during chilling, the carcasses of 10 birds from each group were immediately trimmed for breast and thigh meat by removing skin, bones and connective tissues. Subsequent, the breast and thigh meat within each group was separately sliced, over-wrapped in the transparent oxygen-permeable polyvinyl chloride film and stored at $4^{\circ} \mathrm{C}$ for 24 and $72 \mathrm{~h}$. A second part of samples of breast and thigh muscles was packed in the polyethylene sacks and was stored in freezer at $-18^{\circ} \mathrm{C}$ during 2 and 6 months. Ahead of LPO analysis, the frozen samples were defrost at the chilling conditions $\left(4^{\circ} \mathrm{C}\right)$ for $12 \mathrm{~h}$, homogenized and analysed immediately.

Thiobarbituric acid reactive substances (TBARS) were expressed as the amount of malondialdehyde (MDA) calculated per $1 \mathrm{~kg}$ of meat sample. MDA was measured spectrophotometrically at $532 \mathrm{~nm}$ (Helios $\gamma$, v. 4.6, Thermo spectronic, GB) according to Marcinčák et al. (2006).

Peroxide value examination was done according to the Veterinary Laboratory Methods (Edict of Ministry of Agriculture of Slovak Republic, 2003, No. 149/1/2003-100). 
After preceding the wet mineralization in the microwave oven MLS 1200, the concentration of copper, zinc and iron in all samples was analysed by the flame AAS method (Perkin Elmer, AAnalyst 100), whereas the concentration of manganese was determined by the flameless AAS method (Perkin Elmer, 4100 ZL) and the concentration of selenium was measured by the same instrument equipped with a hydride generation system (Perkin Elmer, 4100 ZL with a quartz cuvette).

\section{Statistical analysis}

Statistical analysis was done using one-way analysis of variance (ANOVA) with the post hoc Tukey's multiple comparison test by the statistical software GrafPad Prism, Version 4.00 (2003).

\section{RESULTS AND DISCUSSION}

The differences in the carcass weights (g: $1803 \pm 210.1,1721 \pm 155.1$, $1817 \pm 153.2$ and $1839 \pm 122.7$, respectively), breast parts in $\%$ of carcass weights (24.93, 25.53, 23.97 and 25.08, respectively) and thigh parts in \% of carcass weights $(29.33,29.68,28.3$ and 28.11, respectively) found in all experimental groups of chickens after the slaughter, were not statistically significant. Nollet et al. $(2007,2008)$ found no significant differences in the body weight between the groups of broilers fed the diets supplemented with 100, 67, 50, 33 and $17 \%$ of recommended dose of the organic form of minerals (Bioplex $\mathrm{Cu}$, Bioplex $\mathrm{Fe}$, Bioplex $\mathrm{Zn}$, Bioplex Mn). The addition of trace elements $(\mathrm{Cu}, \mathrm{Fe}, \mathrm{Zn}, \mathrm{Mn}$ and $\mathrm{Se}$ ) in the organic "proteinated" form into the diet could be reduced to $33 \%$ of regular levels with comparison to the supplementation of their inorganic salts, without compromising the body weight of broilers (Peric et al., 2006; Nollet et al., 2007). These findings could be in accordance with our results especially when we considere that there is a linear correlation between the body weight and carcass weight. Rossi et al. (2007) observed that the body weight of broiler chickens was not affected by the form of $\mathrm{Zn}$ and Se presented in the diet but the carcass quality was improved only in the groups of birds fed the diet supplemented with the organic form of trace elements.

The concentration of $\mathrm{Cu}, \mathrm{Fe}, \mathrm{Zn}$ and $\mathrm{Mn}$ in the breast and thigh muscle was not significantly different within the groups of chickens but the concentration of iron and zinc was approximately two times higher in the thigh muscle compared to the breast muscle (Table 2). This could be explained by the different nature of both muscles as mentioned thereinafter. The concentration of Se in the breast and 
Table 2. The effects of supplementation of the diet for broiler chickens with different form and amount of $\mathrm{Cu}, \mathrm{Fe}, \mathrm{Zn}, \mathrm{Mn}$ and $\mathrm{Se}$ on the concentration of these trace elements $\left(\mathrm{mg} / \mathrm{kg}^{-1} \mathrm{DM}\right)$ in breast and thigh muscle after slaughter

\begin{tabular}{|c|c|c|c|c|c|c|c|c|c|c|}
\hline \multirow{3}{*}{$\begin{array}{l}\text { Trace } \\
\text { elements }\end{array}$} & \multicolumn{5}{|c|}{ Breast muscle } & \multicolumn{5}{|c|}{ Thigh muscle } \\
\hline & \multicolumn{10}{|c|}{ group } \\
\hline & $1^{\mathrm{st}}$ & $2^{\text {nd }}$ & $3^{\text {rd }}$ & $4^{\text {th }}$ & SD & $1^{\text {st }}$ & $2^{\text {nd }}$ & $3^{\text {rd }}$ & $4^{\text {th }}$ & SD \\
\hline Copper & 0.77 & 0.75 & 0.76 & 0.65 & 0.14 & 0.78 & 0.75 & 0.74 & 0.73 & 0.08 \\
\hline Iron & 3.22 & 3.46 & 3.24 & 2.91 & 0.51 & 5.44 & 4.62 & 5.02 & 5.1 & 1.42 \\
\hline Zinc & 5.43 & 5.33 & 5.36 & 5.4 & 0.33 & 10.54 & 12.05 & 10.67 & 12.99 & 3.35 \\
\hline Manganese & 0.1 & 0.09 & 0.08 & 0.09 & 0.01 & 0.15 & 0.11 & 0.1 & 0.1 & 0.03 \\
\hline Selenium & $0.12^{\mathrm{A}}$ & $0.30^{\mathrm{B}}$ & $0.12^{\mathrm{A}}$ & $0.28^{\mathrm{B}}$ & 0.02 & $0.15^{\mathrm{A}}$ & $0.27^{\mathrm{B}}$ & $0.12^{\mathrm{A}}$ & $0.28^{\mathrm{B}}$ & 0.02 \\
\hline
\end{tabular}

distinct superscripts within row - significant difference ( $\left.{ }^{\mathrm{XY}} \mathrm{P}<0.001\right)$. Values are means; $\mathrm{n}=10$

thigh muscle shown the pattern of Se deposition only in the groups of birds supplemented with the selenized yeast. Schrauzer (2000) found the proportion of selenomethionine, that is escaping metabolism to $\mathrm{H}_{2} \mathrm{Se}$, is non-specifically incorporated into the structural proteins of muscles, where it replaces common methionine. On the other hand, sodium selenite is unable to build significant $\mathrm{Se}$ deposits in the muscle of poultry (Kuricová et al., 2003; Petrovič et al., 2006) and is rapidly excreted with other trace elements in the inorganic form via the faeces of birds (Nollet et al., 2007).

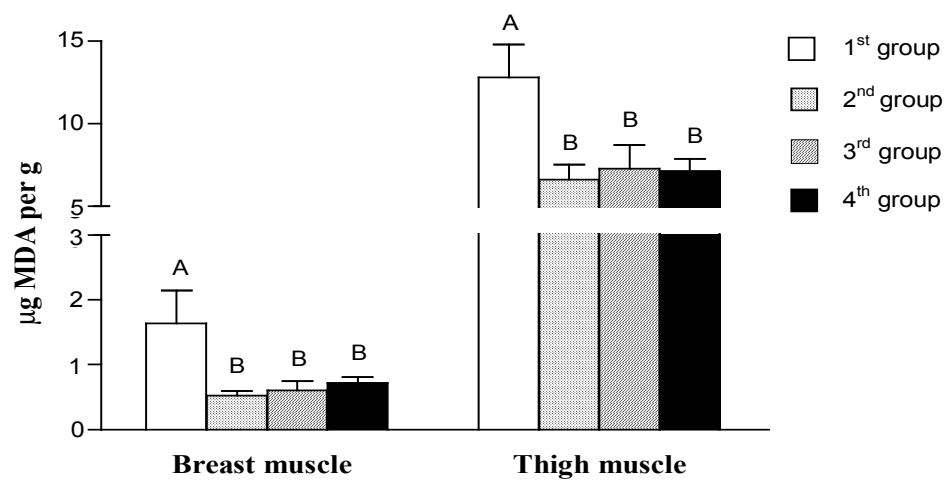

Figure 1. The effects of supplementation of the diet for broiler chickens with different form and amount of $\mathrm{Cu}, \mathrm{Fe}, \mathrm{Zn}, \mathrm{Mn}$ and $\mathrm{Se}$ on the peroxide values in breast and thigh muscle assessed after $24 \mathrm{~h}$ storage at $+4^{\circ} \mathrm{C}$. Values are means $\pm \mathrm{SD}, \mathrm{n}=10$ in each group. Distinct letters above columns mean significant differences between treatments $\left.{ }^{\mathrm{XY}} \mathrm{P}<0.001\right)$

From the results found in the $1^{\text {st }}$ group of birds it is apparent that the supplementation of diet only with the inorganic forms of trace elements $(\mathrm{Cu}, \mathrm{Fe}, \mathrm{Zn}, \mathrm{Mn}$ and $\mathrm{Se}$ ) significantly influences the lipid peroxidation (LPO) by increasing the peroxide number (Figure 1, Table 3) as well as the TBARS 
Table 3. The effects of supplementation of the diet for broiler chickens with different form and amount of $\mathrm{Cu}, \mathrm{Fe}, \mathrm{Zn}, \mathrm{Mn}$ and $\mathrm{Se}$ on the peroxide values $\left(\mu \mathrm{g} / \mathrm{g}^{-1}\right)$ in breast and thigh muscle assessed after the refrigerated and frozen storage

\begin{tabular}{|c|c|c|c|c|c|c|c|c|c|c|}
\hline \multirow{3}{*}{$\begin{array}{l}\text { Storage time, } \\
\text { temp. }\end{array}$} & \multicolumn{5}{|c|}{ Breast muscle } & \multicolumn{5}{|c|}{ Thigh muscle } \\
\hline & \multicolumn{10}{|c|}{ group } \\
\hline & $1^{\text {st }}$ & $2^{\text {nd }}$ & $3^{\text {rd }}$ & $4^{\text {th }}$ & SD & $1^{\text {st }}$ & $2^{\text {nd }}$ & $3^{\text {rd }}$ & $4^{\text {th }}$ & SD \\
\hline $72 \mathrm{~h},+4^{\circ} \mathrm{C}$ & $8.97^{\mathrm{A}}$ & $4.37^{\mathrm{B}}$ & $3.16^{\mathrm{B}}$ & $4.05^{\mathrm{B}}$ & 1.43 & $16.85^{\mathrm{A}}$ & $12.03^{\mathrm{b}}$ & $13.75^{\mathrm{B}}$ & $12.74^{\mathrm{b}}$ & 3.04 \\
\hline 2 months, $-18^{\circ} \mathrm{C}$ & $3.63^{\mathrm{A}}$ & $1.45^{\mathrm{B}}$ & $1.56^{\mathrm{B}}$ & $1.53^{\mathrm{B}}$ & 0.23 & $25.91^{\mathrm{A}}$ & $17.2^{\mathrm{B}}$ & $14.1^{\mathrm{C}}$ & $18.3^{\mathrm{B}}$ & 1.33 \\
\hline 6 months, $-18^{\circ} \mathrm{C}$ & $17.4^{\mathrm{A}}$ & $7.8^{\mathrm{b}}$ & $9.21^{\mathrm{c}}$ & $11.2^{\mathrm{D}}$ & 0.78 & $69.3^{\mathrm{A}}$ & $30.9^{\mathrm{B}}$ & $25.2^{\mathrm{C}}$ & $44.7^{\mathrm{D}}$ & 2.4 \\
\hline
\end{tabular}

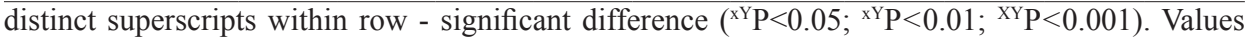
are means; $\mathrm{n}=10$

Table 4. The effects of supplementation of the diet for broiler chickens with different forms and amounts of $\mathrm{Cu}, \mathrm{Fe}, \mathrm{Zn}, \mathrm{Mn}$ and $\mathrm{Se}$ on the thiobarbituric acid reactive substances ( $\mu \mathrm{g} \mathrm{MDA} \cdot \mathrm{g}^{-1}$ ) in breast and thigh muscle assessed after the refrigerated and frozen storage

\begin{tabular}{|c|c|c|c|c|c|c|c|c|c|c|}
\hline \multirow{3}{*}{$\begin{array}{l}\text { Storage time, } \\
\text { temp. }\end{array}$} & \multicolumn{5}{|c|}{ Breast muscle } & \multicolumn{5}{|c|}{ Thigh muscle } \\
\hline & \multicolumn{10}{|c|}{ group } \\
\hline & $1^{\text {st }}$ & $2^{\text {nd }}$ & $3^{\text {rd }}$ & $4^{\text {th }}$ & SD & $1^{\text {st }}$ & $2^{\text {nd }}$ & $3^{\text {rd }}$ & $4^{\text {th }}$ & SD \\
\hline $24 \mathrm{~h},+4^{\circ} \mathrm{C}$ & 0.056 & 0.053 & 0.05 & 0.043 & 0.014 & 0.217 & 0.151 & 0.181 & 0.176 & 0.047 \\
\hline $72 \mathrm{~h},+4^{\circ} \mathrm{C}$ & 0.064 & 0.051 & 0.058 & 0.057 & 0.019 & $0.296^{\mathrm{A}}$ & $0.218^{\mathrm{b}}$ & $0.169^{\mathrm{B}}$ & $0.192^{\mathrm{b}}$ & 0.056 \\
\hline 2 months $-18^{\circ} \mathrm{C}$ & $0.057^{\mathrm{A}}$ & $0.052^{\mathrm{A}}$ & $0.048^{\mathrm{a}}$ & $0.037^{\mathrm{B}}$ & 0.008 & $0.228^{\mathrm{A}}$ & $0.155^{\mathrm{B}}$ & $0.182^{\mathrm{b}}$ & $0.177^{\mathrm{b}}$ & 0.026 \\
\hline 6 months, $-18^{\circ} \mathrm{C}$ & $0.081^{\mathrm{A}}$ & $0.064^{\mathrm{B}}$ & $0.06^{\mathrm{B}}$ & $0.054^{\mathrm{C}}$ & 0.006 & $0.32^{\mathrm{A}}$ & $0.198^{\mathrm{b}}$ & $0.221^{\mathrm{b}}$ & $0.196^{\mathrm{b}}$ & 0.015 \\
\hline
\end{tabular}

distinct superscripts within row - significant difference $\left({ }^{\mathrm{xy}} \mathrm{P}<0.01 ;{ }^{\mathrm{XY}} \mathrm{P}<0.001\right)$. Values are means; $\mathrm{n}=10$

(Table 4) in the poultry meat. In recent experiments, the increased MDA levels in the organs of chickens revealed the pro-oxidative properties of sodium selenite (Balogh et al., 2004; Petrovič et al., 2006). The formation of superoxide anion during the reduction of selenite into $\mathrm{H}_{2} \mathrm{Se}$ (selenide) by glutathione in the cells induced LPO (Kobayashi et al., 2001). Moreover, the superoxide anion formed during this redox reaction could cause that the transition metals from the supplemented inorganic salts are not bound to the proteins and instead catalyse the formation of hydroxyl radical what subsequently increase LPO. This statement could be considered as a pure speculation but can explain the increased peroxide value and malondialdehyde value in muscles of chickens in $1^{\text {st }}$ experimental group. On the other hand, the negative interactions between the elements declined when their proteinated forms were supplemented into the diet (Du et al., 1996), which is in accordance with the results found in $2^{\text {nd }}, 3^{\text {rd }}$ and $4^{\text {th }}$ experimantal group of chickens.

Chicken thigh muscles are considered oxidative with more mitochondria and a higher content of myoglobin compared to glycolytic breast muscles. Oxidative muscles use fatty acids as energy substrates and have lower activities of phosphorylases than the glycolytic muscles which use glycogen as a source of 
energy. The higher levels of lipid peroxidation in the thigh muscle compared to the breast muscle confirmed the presence of higher amount of fatty acids in this part of chicken meat.

It is hypothesized, that in slaughtered animals the Fe containing haem groups of haemoglobin and myoglobin play an important role in the biochemical processes that turn the muscle into meat and thus influence the resistance of meat during its storage. The latter fact is of importance as the poultry meat contains a significantly higher concentration of haemoglobin as compared to other tissues and organs (Kranen et al., 1999). Moreover, the addition of manganese into the broiler diet decreased MDA content in the leg muscle by increasing the MnSOD activity (Lu et al., 2006) and might reduce the fat deposition by decreasing the activities of lipoprotein lipase and malate dehydrogenase activities or increasing the activity of hormone-sensitive lipase in the adipose tissue ( $\mathrm{Lu}$ et al., 2007). The reduced amount of supplemented trace elements in the organic form in the $4^{\text {th }}$ group of broilers had more beneficial effect on the lipid peroxidation than the supplementation of large portion of trace minerals in the inorganic form in the $1^{\text {st }}$ group. This could be explained probably due to a higher bioavailability of nutrients presented in a feed in the proteinated form.

\section{CONCLUSIONS}

In conclusion, the feeding of diet supplemented with the organic form of trace elements, which were reduced to $50 \%(\mathrm{Cu}), 20 \%(\mathrm{Fe}, \mathrm{Zn}$ and $\mathrm{Mn})$ and on its regular level (Se) have the same effect on the body weight, weight of breast and thigh parts and the concentration of supplemented minerals (except of Se) in the muscles as the feeding of diet with recommended dose of nutrients in the inorganic form. The selenized yeast showed to be more effective in the formation of Se deposit in the muscle of broilers than sodium selenite. On the other hand, the feeding of diet supplemented only with inorganic forms of $\mathrm{Cu}, \mathrm{Fe}, \mathrm{Zn}, \mathrm{Mn}$ and Se influenced the quality of broiler meat assessed after the refrigerated and frozen storage. The peroxide value and malondialdehyde value increased significantly in breast and thigh muscle of chickens in this group, what could be possibly explained by the negative interactions between sodium selenite and transition metal ions when supplemented in the form of inorganic salts.

\section{REFERENCES}

Aruoma O.I., Halliwell B., Gajewsky E., Dizdaroglu M., 1991. Copper-iron dependent damage to the bases of DNA in the presence of hydrogen peroxide. Biochem. J. 273, 2601-2064 
Balogh K., Weber M., Erdelyi M., Mezes M., 2004. Effect of excess selenium supplementation on the glutathione redox system in broiler chicken. Acta Vet. Hung. 52, 403-411

Bugarský A., Hockicko T., Vargová M., Buleca Jr. J., Bajan L., Korim P., Hadbavný M., 2003. Cruelty to animals as an unlawful action. Folia Vet. 47, 52-55

Carnevale de Almeida J., Perassolo M.S., Camargo J.L.,Bragagnolo N., Gross J.L., 2006. Fatty acid composition and cholesterol content of beef and chicken meat in Southern Brasil. Braz. J. Pharm. Sci. 42, 109-117

Cortinas L., Barroeta A., Villaverde C., Galobart J., Guardiola F., Baucells M.D., 2005. Influence of the dietary polyunsaturation level on chicken meat quality: Lipid oxidation. Poultry Sci. 84, 487-455

Du Z., Hemken R.W., Jackson J.A., Trammell D.S., 1996. Utilization of copper in copper proteinate, copper lysine, and cupric sulfate using the rat as an experimental model. J. Anim. Sci. 74, 16571663

Edict of Ministry of Agriculture of Slovak Republic, 2003. No. 149/1/2003-100

Higgins F.M., Kerry J.P., Buckley D.J., Morryssey P.A., 1999. Effects of $\alpha$-tocoferyl acetate supplementation and salt addition on the oxidative stability (TBARS) and warmed-over flavour (WOF) of cooked turkey meat. Brit. Poultry Sci. 40, 59-64

Kobayashi Y., Ogra Y., Suzuki K.T., 2001. Speciation and metabolism of selenium injected with ${ }^{82} \mathrm{Se}$-enriched selenite and selenate in rats. J. Chromatogr. 760, 73-81

Kranen R.W., Van Kuppevelt T.H., Goedhart H.A., Veerkamp C.H., Lambooy E., Veerkamp J.H., 1999. Hemoglobin and myoglobin content in muscles of broiler chickens. Poultry Sci. 78, 467-476

Kuricová S., Boldižárová K., Grešáková L', Levkut M., Leng L., 2003. Chicken selenium status when fed a diet supplemented with Se-yeast. Acta Vet. Brno 72, 339-346

Lu L., Ji C., Luo X.G., Liu B., Yu S.X., 2006. The effect of supplemental manganese in broiler diets on abdominal fat deposition and meat quality. Anim. Feed Sci. Tech. 129, 49-59

Lu L., Luo X.G., Ji C., Liu B., Yu S.X., 2007. Effect of manganese supplementation and source on carcass traits, meat quality, and lipid oxidation in broilers. J. Anim. Sci. 85, 812-822

Marcinčák S., Sokol J., Turek P., Popelka P., Nagy J., 2006. Determination of malondialdehyde in pork meat using solid phase extraction and HPLC. Chem. Listy 100, 528-532

Nollet L., Huyghebaert G., Spring P., 2008. Effect of different levels of dietary organic (Biolpex) trace minerals on live performance of broiler chickens by growth phases. J. Appl. Poultry Res. $17,109-115$

Nollet L., van der Klis J.D., Lensing M., Spring P., 2007. The effect of replacing inorganic with organic trace minerals in broiler diets on productive performance and mineral excretion. J. Appl. Poultry Res. 16, 592-597

Peric L., Nollet L., Miloševic N., Žikic D., 2006. Effect of Bioplex and Sel-Plex substituting inorganic trace mineral sources on performance of broilers. Arch. Geflügelk. 71, 122-129

Petrovič V., Boldižárová K., Faix Š., Mellen M., Arpašová H., Leng. L., 2006. Antioxidant and selenium status of laying hens fed with diets supplemented with selenite or Se-yeast. J. Anim. Feed Sci. 15, 435-445

Pípová M., Cabadaj R., Nagy J., 1995. Hygiene of Poultry, Eggs, Fish, and Game. Data Help Press, Košice (Slovak Republic)

Rossi P., Rutz F., Anciuti M.A., Rech J.L., Zauk N.H.F., 2007. Influence of graded levels of organic zinc on growth performance and carcass traits of broilers. J. Appl. Poultry Res. 16, 219-225

Schrauzer G.N., 2000. Selenomethionine: A review of its nutritional significance, metabolism and toxicity. J. Nutr. 130, 1653-1656

Surai P.F., 2002. Selenium in poultry nutrition 1. Antioxidant properties, deficiency and toxicity. World Poultry Sci. J. 58, 333-347

Tirosh O., Reznick A.Z., 2000. Chemical bases and biological relevance of protein oxidation. In: C.K. Sen, L. Packer, O.O.P. Hanninen (Editors). Handbook of Oxidants and Antioxidants in Exercise. Elsevier, Amsterdam, pp. 89-114 